\section{Leverhulme Research Fellowships, 1951}

THE following awards for research, tenable for periods up to two years, and for the subjects mentioned, have been made by the trustees of the Leverhulme Fellowships: Fellowships : T. J. Dunbabin, fellow and reader in classical archæology, All Souls College, Oxford (Greece and the Orient in the eighth and seventh centuries, B.C.); Dr. R. F. Fortune, senior lecturer in anthropology, University of Cambridge (investigation of change in central New Guinea highlands societies since pre-conquest observations in 1935); Miss P. M. Kemp, formerly lecturer, University of Allahabad (household economy and technology of some tribal communities, Punjab); .M. C. K. Tweedie, Laboratory of Human Nutrition, University of Oxford (statistical estimation problems in non-Gaussian distributions). Research Grants : Miss B. de Cardi, assistant secretary, Council for British Archæology (an exploratory survey of prehistoric sites on the eastern borders of Baluchistan); Mrs. S. Davis, Extra-Mural Department, University of Manchester (agriculture in Cheshire, 1750-1850, in relation to contemporary industry); R. C. Ellis, education officer and headmaster, Basutoland High School, Maseru (Basotho indigenous songs and verse); J. M. Hartog, joint reader, Oxford and Cambridge Spitsbergen Expedition, 1951 (photographic and cartographic work in connexion with the Expedition); E. M. Jope, Department of Archæology, Queen's University, Belfast (economic geography of the Oxford region in the Middle Ages); Dr. W. G. Keyworth, East Malling Research Station (hop diseases in the United States and current research on Verti. cillium wilts); Miss J. M. Lambert, Leverhulme Research Fellow (ecological investigations into the vegetation in the region of the Norfolk Broads); G. F. Mitchell, fellow and tutor in geology, Trinity College, Dublin (plant fossils from late-glacial and post-glacial deposits in the British Isles); T. B. Mitford, lecturer in humanity, University of St. Andrews (continuation of archæological research in Cyprus); Dr. J. Needham, Caius College, Cambridge (completion of a study of science, scientific thought and technology in the Far East). Further information can be obtained from the Secretary, Leverhulme Research Fellowships, 3-5 Salisbury Square, London, E.C.4.

\section{Kalinga Prize for Scientific Popularization}

As international annual prize of $£ 1,000$ sterling for the best works of scientific popularization has been established by Mr. M. B. Patnaik, an Indian industrialist, and will be awarded under the auspices of Unesco. The prize will bear the name of Kalinga, the empire which covered part of India and Indonesia three centuries before the Christian era, and which was conquered by the Emperor Asoka, who resolved, on the occasion of his conversion to Buddhism, never again to resort to the use of armed force. In cooperation with the International Council of Scientific Unions, Unesco will draw up and publish the rules for competition for the prize; and the first award will be made in 1952. Further information can be obtained from Unesco, 19 Avenue Kleber, Paris XVIe.

\section{Announcements}

Prof. A. A. Hall, Zaharoff professor of aviation in the University of London and head of the Department of Aeronautics, Imperial College of Science and Technology, has been appointed director of the Royal
Aircraft Establishment, Farnborough, in succession to the late Mr. W. G. A. Perring. Prof. Hall worked at Farnborough during 1938-45, before going to the Imperial College (see Nature, August 19, 1944, p. 234).

THE honorary degree of D.Sc. of the University of Birmingham has been conferred on Sir James Chadwick, master of Gonville and Caius College, Cam. bridge, Sir Robert Davis, inventor of the Davis submarine escape apparatus, and Sir John Simonsen, director of research, Colonial Products Research Council.

DR. G. L. S. ShackLE, reader in economic theory in the University of Leeds, has been appointed to the Brunner chair of economic science in the University of Liverpool.

THe following appointments have recently been made in the University of Sheffield: Dr. M. A. G. Kaye to be lecturer in biochemistry; Dr. W. S. Bullough to be honorary lecturer in zoology.

Dr. A. M. Macbeath has recently been appointed lecturer in mathematics in the University College of North Staffordshire. The following have been appointed assistant lecturers in the subjects shown: E. M. Yates and Dr. Monica M. Cole (geography), Dr. D. E. Davies and A. A. Shepherd (physics), T. H. White and H. Spedding (chemistry), Ruth M. Badeock (biology), F. Moseley and R. Barrass (geology).

The Adams Prize for 1949-50 of the University of Cambridge has been awarded jointly to the following, for essays on the subjects mentioned: Dr. G. K. Batchelor ("The Theory of Homogeneous Turbulence"); Mr. W. R. Dean ("Problems in the Motion of an Incompressible Viscous Fluid"); Dr. L. Howarth ("Some Aspects of Boundary Layer Theory").

THe British Welding Research Association announces the following appointments : Dr. Nicol Gross, to be assistant director of research, while remaining in charge of the Association's research station at Abington; Dr. K. Winterton and H. E. Dixon, to be chief metallurgists, the former for ferrous metals, and the latter for non-ferrous metals; C. L. M. Cottrell and P. T. Houldcroft, to be assistant chief metallurgists for ferrous and non-ferrous metals respectively.

Sir Wruliam Taylor, a member of the Nature Conservancy and formerly director-general of the Forestry Commission, has been appointed a member of the National Parks Commission to fill the vacancy created by the resignation of Mr. E. W. Wimble.

THE first two volumes of the proceedings of the polarographic congress, held in Prague during February (see Nature, March 24, p. 464), are now ready. Volume 1 contains forty-four communications, in English, German, French or Italian, sent as contributions to be published in honour of Prof. $J$. Heyrovský's sixtieth birthday (about $550 \mathrm{pp}$.), and abbreviated papers presented at the Congress in Russian, German, English or French (about 200 pp.). Volume 2 presents a full bibliography of polarography (1922-50), revised by Prof. Heyrovský and his collaborators (about 250 pp.) ; Russian polarographic publications are quoted in Russian characters. Inquiries about these volumes should be sent to Orbis-Export-Import, Prague I., Národni 37, Czechoslovakia. 